\title{
The primary market of parking places against the background of the primary housing market and planning policy on the example of Krakow
}

\author{
Krzysztof Butryn ${ }^{1}$, Edward Preweda ${ }^{2}$ \\ ${ }^{1}$ Department of Geomatics, Faculty of Mining Surveying and Environmental Engineering, \\ AGH University of Science and Technology in Kraków, Poland \\ ${ }^{2}$ Department of Geomatics, Faculty of Mining Surveying and Environmental Engineering, \\ AGH University of Science and Technology in Kraków, Poland \\ E-mail: ${ }^{1}$ kbutryn@agh.edu.pl ${ }^{2}$ edward.preweda@agh.edu.pl
}

\begin{abstract}
A decision taken on the primary market of real estate in parallel with the decision to purchase a dwelling, it is often the purchase of a parking space. As part of this work there were presented forms of providing space for parking, mostly encountered in practice. In the following, there were carried out the characterization of the primary market of parking spaces on the example of Krakow. There was made an attempt to indicate the potential attributes of price-setting for the valuation of the unit value of the discussed objects. Studies have shown that the price of parking spaces are formed in a different way than the market for residential and largely depend on individual factors, dependent on the sales policy developers. There were also indicated the difficulties that meets a real estate appraiser, whose task is to measure the market value of the parking space.

The analysis also included the resolutions of existing planning documents in shaping the requirements for the number of parking spaces for multi-family residential areas in Krakow. Overview of planning documents from the Krakow, points to trends in the rules of applicable local spatial management plans in relation to the required number of parking spaces for newly established housing investment. At the same time in most parts of the city there is no planning guidelines regarding the subject matter.
\end{abstract}

Keywords: parking space, property valuation, land use planning

Conference topic: Technologies of Geodesy and Cadastre

\section{Introduction}

The decision to buy a dwelling is for many people, especially young people, one of the most important and carrying the serious financial consequences decisions in life. In Polish culture, possession of property ownership is deeply rooted. Almost every person between 20-th and 30-th year of life begins at some time actively looking out for his own flat. At the same time the imperfections of the public transport system cause that to be mobile, almost necessary is to have an own car. For this reason, a decision taken on the real estate market in parallel with the purchase of a dwelling, it is often the purchase of a parking space.

Primary markets of residential units in major Polish cities, including Krakow, are developing rapidly in recent years (Raport 2015), the supply of new flats steadily increases. At the same time the huge problem of most new settlements is insufficient number of parking spaces for residents, not to mention the cars of guests. The result is that the market of parking spaces does not develop in parallel with the residential market, and prices influence other than in the case of housing factors (Butryn, Preweda 2016). Additionally, in practice there are distinguished different types of legal organization of a parking space (Jasińska 2015). In this study there were conducted characteristics of the local primary market of the parking spaces from the area of Krakow and identified potential factors affecting the price and value of these objects, and the difficulties encountered by the property appraiser, whose task is to determine the market value of the parking space.

An important aspect of local politics in terms of ensuring an adequate number of parking spaces are provisions of local spatial management plans (Ustawa 2003). Analysis acquired, therefore, the provisions of the existing planning documents in shaping the requirements for the number of parking spaces for multi-family residential areas. Overview of planning documents from the Cracow points to trends in the rules of governing local spatial management plans in the context of the required parking spaces for newly established housing investment. At the same time, in most parts of the city there is no valid planning recommendations regarding the subject matter.

(C) 2017 Krzysztof Butryn, Edward Preweda. Published by VGTU Press. This is an open-access article distributed under the terms of the Creative Commons Attribution (CC BY-NC 4.0) License, which permits unrestricted use, distribution, and reproduction in any medium, provided the original author and source are credited. 


\section{Types of parking places associated with multi-family housing}

The developer which implements investment in the field of multi-family housing has a statutory obligation to provide parking spaces for residents. This is due to the findings of $\S 18$ of the Regulation of the Minister of Infrastructure of 12 April 2002 on the technical conditions to be met by buildings and their locations (Rozporządzenie 2002). At the same time the developer is forced to provide a number of places, which is specified in planning documents - the zoning plan, and in the absence of a plan - zoning and land use decision. This is a result of the findings in the verdict of the Supreme Administrative Court of 12 October 2012 (judgment in the case under file number II OSK 812/11) (Wyrok 2012).

In practice, we can distinguish different types of space to park connected with multi-family housing. Under the term of parking space there is understood a separate part of a multi garage, located mostly in the underground floor of the multifamily residential building. Garage is at the same time an integral part of the building.

Separation of individual parking spaces is done by plotting a line on the floor separating the different places. Such separation of parking space carries a number of complications in Polish legislation. Firstly, it cannot be treated as a separate premises, because it does not meet the definition of premises contained in Article 2 paragraph. 2 of the Act of 24 June 1994. Of property units (Ustawa 1994).

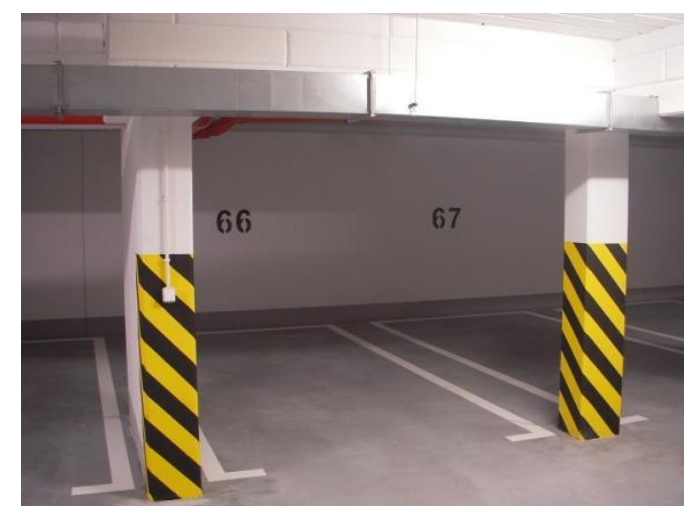

Fig. 1. Parking space in the underground multiposition garage (Source: author's own archive)

According to the current wording of this provision, an independent commercial property is separated by permanent walls within the building or set of chambers. Parking space separated by a line drawn on the ground does not meet the necessary conditions, it cannot therefore constitute a separate residential property. Additionally, the parking space separated in this way, cannot be a belonging space (Postanowienie 2005). In view of the above limitations, in practice, there are two solutions - parking space as an easement and parking space as a share in the ownership of the garage, which is separated as a separate stand-alone premises.

Table 1. Parking space in the underground multiuser garage - legal solutions (Source: own studies based on Jasińska 2015, Puch 2010 )

\begin{tabular}{|c|c|c|}
\hline Applied solution & The essence of solution & Characteristics \\
\hline Parking space as an easement & $\begin{array}{l}\text { Parking permit through the establish- } \\
\text { ment of an easement parking } \\
\text { at a particular place in the garage. }\end{array}$ & $\begin{array}{l}\rightarrow \text { garage is a part of common property } \\
\rightarrow \text { to individual co-owners shall be es- } \\
\text { tablished parking easement } \\
\rightarrow \text { there is no possibility of the sale } \\
\text { of a parking space separately } \\
\text { from flat }\end{array}$ \\
\hline Garage - a separate premises & $\begin{array}{l}\text { Parking permit through participation } \\
\text { in the ownership of the garage, } \\
\text { which is a separate property }\end{array}$ & $\begin{array}{l}\rightarrow \text { multiposition garage become } \\
\text { a separate, stand-alone premises } \\
\rightarrow \text { right to use a parking space as a } \\
\text { share of the ownership of the garage } \\
\text { premises } \\
\rightarrow \text { the possibility of the sale of a park- } \\
\text { ing space in disconnecting } \\
\text { from the apartment }\end{array}$ \\
\hline
\end{tabular}

In practice, the more often can be met the solution of separating the garage as an independent property. Besides, this form is recommended by Polish jurisdiction. 
Above there were presented forms of organization of legal parking spaces located in the multi garages, usually held in the basement of the building. Apart from them, often common form of providing space for parking are external parking spaces. In this case also there may be different solutions. Firstly, there may be a situation where there is no specific regulation and external parking places are accessible to all residents. Parking takes on a "first come, first served" basis. Second, it can be done the assignment of rights of exclusive use of a parking space for the owner of a dwelling. This is done on the basis of a contract quoad usum, which regulates the use of the common property. Thirdly, there may be assigning of parking spaces specific to the owners based on the findings of a residential community. There is also the possibility of a situation where parking spaces are a separate land properties. This solution does not work in an area where arrangements of local spatial management plans are applied (Jasińska 2015).

There is, however, a form of assignment of property rights to the garage - separate property constituting the garage which is the subject of a separate ownership. It does not fit, however, for a parking space and is not subject to development under this article.

\section{Primary market - definition}

The real estate market is generally the conditions in which the exchange of rights to property takes place and contracts are concluded, posing mutual rights and obligations connected with the reign of the property (Kucharska-Stasiak 2004.). One of the primary divisions of the real estate market is divided into primary and secondary markets. In this study, the object of interest is the primary market.

The definition of primary real estate market is the same as outlined above definition of the overall real estate market, except that it applies to new properties. To put the definition in some simplification - the primary market of real estate is a market of buildings and premises aimed at meeting the housing needs, which are sold by entrepreneurs.

Traded on the primary market are therefore new property offered by the operators of a real estate development and housing cooperatives. A characteristic feature of the primary market is the fact that it takes place on the new real estate transactions, which for the first time are the subject of the transaction. Transactions take place mostly on the lines of "operator" - "natural person" or "operator" - "operator."

\section{Characteristics of the primary market of parking spaces in Krakow}

As part of the implementation of the issues, there have been collected transaction data on parking spaces, which were traded on Krakow's primary market. The study area includes selected areas of the city, in which there has been observed actively market of these objects. The assessment criterion was the occurrence of activity in the reporting period (last five years) at least 30 transactions in the area of each of the precincts.

At the beginning it should be noted that on the website of the Municipal Spatial Information System of the City of Krakow is published layer mappings, whose source is the Register of Real Estate Prices and Values. It contains information on the average surface premises garage, their average unit prices and total average transaction prices.

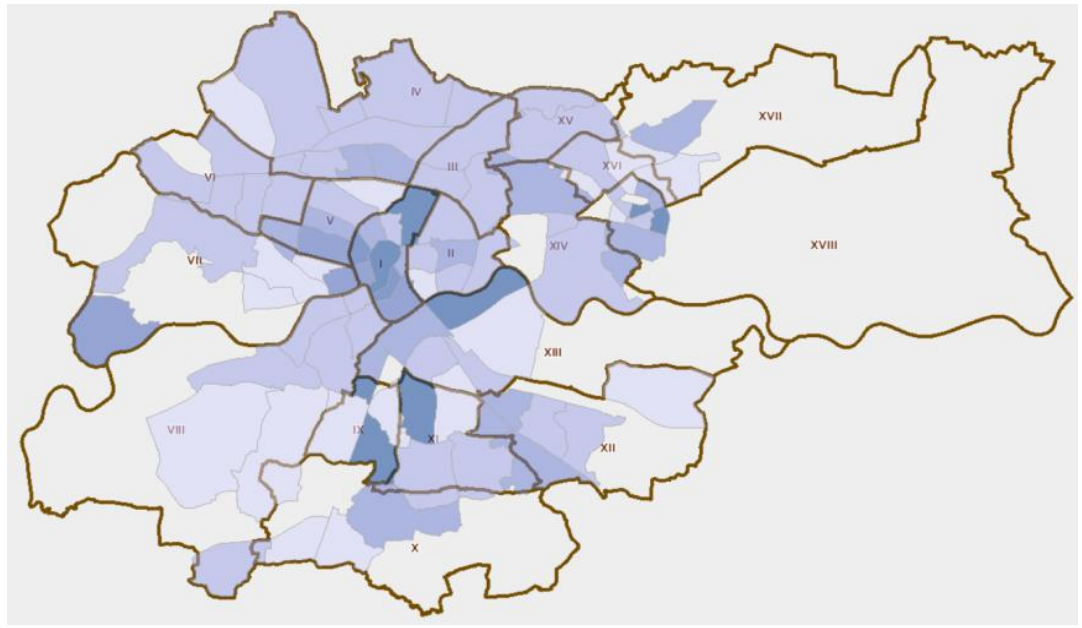

Fig. 2. Price differentiation of garage premises in Krakow based on the Register of Real Estate Prices and Values (source: http://msip2.um.krakow.pl/)

Unfortunately, this layer is useless in the light of the problems discussed in this article. It contains various data, including those which relate to include premises of an entire multi-station underground garage, which contains many individual parking spaces. 
The source of data agreements were concluded in the form of notarial acts. From the data in such documents, there were extracted informations on the price of a parking space. For the analysis there have been selected objects for which it could be clearly inferred the absence of specific conditions of the transaction, which would exclude the definition of market value. The selected base is composed of dedicated parking spaces as part of a separate garage premises. The unit prices were possible to obtain only for the objects of known area, restricted for the operation to an interval corresponding to the typical dimensions of the parking space (from about 12 to about 20 square meters). Below is a figure showing the average unit prices of parking spaces in selected precincts registration Krakow:

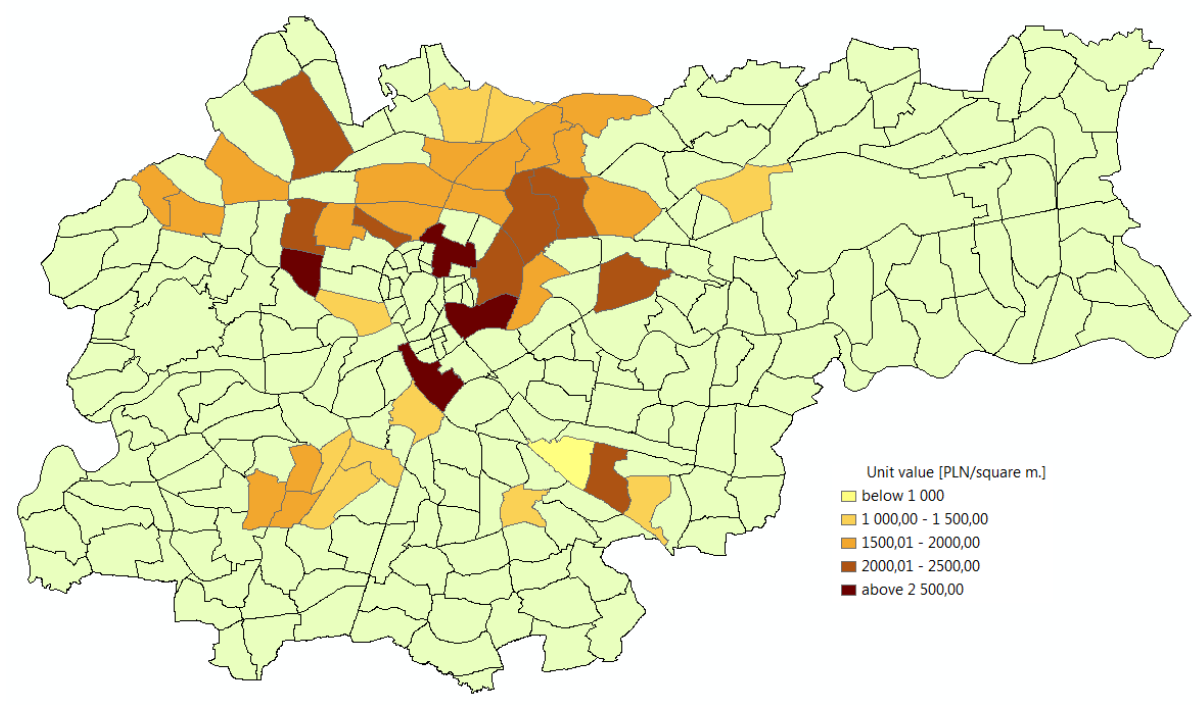

Fig. 3. Average unit prices of parking spaces in Krakow - the primary market (source: own studies)

The highest average unit prices were recorded in the precincts of the cadastral unit Podgórze - 2 132.82 PLN per square meter, the lowest in the foothills - 1593.93 PLN per square meter (while the largest sample size). In the case of residential rates are recorded while in first place in Nowa Huta, then Podgórze (Raport. 2015). It should be noted, however, that these areas are characterized by different activity of developers - very high in the Podgórze, small in Nowa Huta.

Table 2. The average price of parking spaces in selected precincts of the city of Krakow (Source: own studies)

\begin{tabular}{|c|c|c|c|c|c|c|c|c|c|}
\hline No. & Cadastral unit & Precinct & $\begin{array}{c}\text { Unit price } \\
{\left[\mathbf{P L N} / \mathbf{m}^{2}\right]}\end{array}$ & $\begin{array}{c}\text { Average } \\
\text { area }\left[\mathbf{m}^{2}\right]\end{array}$ & No. & Cadastral unit & Precinct & $\begin{array}{c}\text { Unit price } \\
{\left[\mathbf{P L N} / \mathbf{m}^{2}\right]}\end{array}$ & $\begin{array}{c}\text { Average } \\
\text { area }\left[\mathbf{m}^{2}\right]\end{array}$ \\
\hline 1. & Podgórze & 43 & 1145,73 & 17,26 & 21. & Krowodrza & 29 & 1227,83 & 17,04 \\
\hline 2. & Podgórze & 41 & 1591,83 & 12,80 & 22. & Krowodrza & 28 & 1417,76 & 16,98 \\
\hline 3. & Podgórze & 42 & 1784,39 & 14,72 & 23. & Krowodrza & 49 & 1633,40 & 16,14 \\
\hline 4. & Podgórze & 35 & 1646,21 & 13,04 & 24. & Krowodrza & 48 & 1680,00 & 16,10 \\
\hline 5. & Podgórze & 34 & 1353,13 & 15,00 & 25. & Krowodrza & 40 & 1640,76 & 19,68 \\
\hline 6. & Podgórze & 33 & 1260,80 & 16,45 & 26. & Krowodrza & 33 & 2134,90 & 15,19 \\
\hline 7. & Podgórze & 53 & 1034,19 & 13,66 & 27. & Śródmieście & 5 & 2337,95 & 14,04 \\
\hline 8. & Podgórze & 30 & 1109,20 & 17,08 & 28. & Śródmieście & 4 & 2195,43 & 13,80 \\
\hline 9. & Podgórze & 12 & 2956,84 & 17,35 & 29. & Śŕdmieście & 16 & 1900,49 & 15,08 \\
\hline 10. & Podgórze & 55 & 2408,65 & 16,29 & 30. & Śródmieście & 21 & 1535,05 & 17,26 \\
\hline 11. & Podgórze & 57 & 1481,10 & 15,32 & 31. & Śódmieście & 8 & 2638,26 & 13,71 \\
\hline 12. & Podgórze & 61 & 1348,12 & 15,41 & 32. & Śródmieście & 22 & 1752,89 & 17,85 \\
\hline 13. & Krowodrza & 5 & 2550,92 & 15,38 & 33. & Śródmieście & 17 & 2754,97 & 13,91 \\
\hline 14. & Krowodrza & 2 & 2321,30 & 13,66 & 34. & Sródmieście & 23 & 1947,48 & 14,51 \\
\hline 15. & Krowodrza & 14 & 1423,78 & 15,15 & 35. & Nowa Huta & 5 & 1701,88 & 16,98 \\
\hline 16. & Krowodrza & 3 & 1882,78 & 15,55 & 36. & Nowa Huta & 1 & 1634,78 & 15,02 \\
\hline 17. & Krowodrza & 46 & 2138,56 & 17,65 & 37. & Nowa Huta & 7 & 1940,45 & 13,76 \\
\hline 18. & Krowodrza & 44 & 1712,40 & 15,98 & 38. & Nowa Huta & 54 & 2229,06 & 13,00 \\
\hline 19. & Krowodrza & 45 & 1982,45 & 16,98 & 39. & Nowa Huta & 44 & 1349,93 & 14,82 \\
\hline 20. & Krowodrza & 43 & 1533,49 & 14,92 & 40. & Nowa Huta & 6 & 2028,23 & 16,70 \\
\hline
\end{tabular}

Spatial distribution of prices suggests that the location of the property may have a material effect on the price differentials of analyzed objects. It can be seen that the downtown location has a higher unit rate. The location is 
basically the only objective attribute of creating a price, which can be selected in the characterization and analysis of market spaces.

Besides location of the property, which directly affects its value, it is difficult to point out the price-setting attributes of parking spaces. At the same time it can be distinguished the difficulties that can meet real estate appraiser with the task to estimate the market value of the parking space, which will be discussed below.

The first of potential factors and at the same time the difficulty, is the size of a parking space. In accordance with the principle of functioning of the housing market, the measurement surface of the object has an impact on the estimated value of the unit (in the case of residential premises it is inversely proportional relationship), so in the case of the valuation of parking spaces, which will be collected database of similar objects with known surfaces and unit prices, the surface may be a price-setting attribute. Analysis of the provisions of the agreements, however, shows that in the case of parking spaces in the underground multiuser garage, there is not always a given area of a particular place. It is disclosed only mention of participation enjoyed by the purchaser and the total transaction price. This excludes the use of data on such a facility, e.g. in the valuation process using the methodology of comparative approach.

The second of potential factors, related to the physical location of the parking space, is its location within the building (floor). In the case of residential premises, it is one of the basic price-setting attributes, differentiating property prices in both the primary and secondary market (often considered in parallel with the exhibition premises in relation to the world). As a result of small supply of land and the increased demand for parking spaces, and in order to maximize profits from sales, many developers decides to implement a multi-level underground garage. Analysis of the content of notarial acts (sales contracts) leads to the conclusion that, in general, in the case of multi-level underground garage parking space price is higher, the higher the floor - the cheapest are therefore objects to the level of the lowest floor. In the set of analyzed data market, there have been discovered several development projects, within which were sold parking spaces located on more than one floor. Below is an example from one of them.

Table 3. Prices of parking places with the same surfaces located on different floors in the same building (Source: own studies)

\begin{tabular}{|c|c|c|c|}
\hline \multicolumn{4}{|c|}{ LEVEL "-2" } \\
\hline No. & Area $\left[\mathrm{m}^{2}\right]$ & Gross price $[\mathrm{PLN}]$ & Unit price $\left[\mathrm{PLN} / \mathrm{m}^{2}\right]$ \\
\hline 1. & 12,50 & 20000 & 1600,00 \\
\hline 2. & 12,50 & 29000 & 2320,00 \\
\hline 3. & 12,50 & 22800 & 1824,00 \\
\hline 4. & 12,50 & 24000 & 1920,00 \\
\hline 5. & 12,50 & 27000 & 2160,00 \\
\hline 6. & 12,50 & 25000 & 2000,00 \\
\hline 7. & 12,50 & 27000 & 2160,00 \\
\hline 8. & 12,50 & 32000 & 2560,00 \\
\hline 9. & 12,50 & 29000 & 2320,00 \\
\hline 11. & 12,50 & 29000 & 2320,00 \\
\hline 12. & 12,50 & 20000 & 1600,00 \\
\hline 13. & 12,50 & 25000 & 2000,00 \\
\hline 14. & 12,50 & 30000 & 2400,00 \\
\hline 15. & 12,50 & 35000 & 2800,00 \\
\hline 16. & 12,50 & 28000 & 2240,00 \\
\hline 17. & 12,50 & 30000 & 2400,00 \\
\hline 18. & 12,50 & 25000 & 2000,00 \\
\hline 19. & 12,50 & 29000 & 2320,00 \\
\hline 20. & 12,50 & 30000 & 2400,00 \\
\hline
\end{tabular}

\begin{tabular}{|c|c|c|c|}
\hline No. & Area $\left[\mathrm{m}^{2}\right]$ & Gross price $[\mathrm{PLN}]$ & $\begin{array}{l}\text { Unit price } \\
{\left[\mathrm{PLN} / \mathrm{m}^{2}\right]}\end{array}$ \\
\hline 1. & 12,50 & 39000 & 3120,00 \\
\hline 2. & 12,50 & 44000 & 3520,00 \\
\hline 3. & 12,50 & 39000 & 3120,00 \\
\hline 4. & 12,50 & 36000 & 2880,00 \\
\hline 5. & 12,50 & 36500 & 2920,00 \\
\hline 6. & 12,50 & 44000 & 3520,00 \\
\hline 7. & 12,50 & 35550 & 2844,00 \\
\hline 8. & 12,50 & 40000 & 3200,00 \\
\hline 9. & 12,50 & 37000 & 2960,00 \\
\hline 11. & 12,50 & 39500 & 3160,00 \\
\hline 12. & 12,50 & 29000 & 2320,00 \\
\hline 13. & 12,50 & 39000 & 3120,00 \\
\hline 14. & 12,50 & 38000 & 3040,00 \\
\hline 15. & 12,50 & 38000 & 3040,00 \\
\hline 16. & 12,50 & 48000 & 3840,00 \\
\hline 17. & 12,50 & 43000 & 3440,00 \\
\hline 18. & 12,50 & 39500 & 3160,00 \\
\hline 19. & 12,50 & 39500 & 3160,00 \\
\hline 20. & 12,50 & 39000 & 3120,00 \\
\hline
\end{tabular}

The above table contains transaction data for parking places (sold as part of the premises garage, is given surface of the site - the same for each object). It can be seen that the prices of objects located on the first basement level are clearly higher (average of $3170 \mathrm{PLN} / \mathrm{m} 2$ ) than for objects that are located on the lower level (the average price of $2176 \mathrm{PLN} / \mathrm{m} 2)$.

Another potential attribute influencing the price of parking spaces is their location within the garage premises. Higher prices may be offered for parking spaces located in the vicinity of the entrance to the building, elevators, near the entrance gate. The last feature that can really affect the price of the analyzed object is a standard of garage premises, in particular the quality of building materials used, applied facilities.

The above-mentioned potential attributes of price-setting may affect the estimated value of a parking space. The selection forms the basis for further research, in particular trying to determine the quantitative effect of each attribute to the value of the object.

The property appraiser, whose task to estimate the market value of the parking space is required to make a prior analysis of the market, which will enable the selection of the attributes of price-setting real estate (in the case of a comparative approach) or features that differentiate the rate of potential rent (in the case of using the income approach) (Rozporządzenie 2004; Jasińska 2012). The following are the additional difficulties that can accompany the valuation of a parking space: 
$\rightarrow$ notation of price in notary deed: as stated previously, the most common form of the sale of a parking space is participation in a separate apartment garage. Such participation is often purchased on the primary market, together with the ownership of dwelling, and despite well-known (for the buyer) price for the parking space, in the notarial act (notary deed) there is often revealed the total price of an apartment with a parking lot.

$\rightarrow$ no disclosed area of parking place: the situation is also associated with the parking spaces sold as participation of the garage premises. In the absence of a clearly defined area of a parking space, use it as a property in the comparative valuation process is impossible. In extreme cases, the comparative base will be formed only by places with unknown areas - known only the total transaction price. Many experts in a similar situation, evaluates the total market value as the arithmetic mean of the appropriate numerical comparative base (the omission of the unit value occurs). Such action is obviously not consistent with the law and professional standards.

$\rightarrow$ specifics of investments in which parking space is located such a situation may arise when the building in which the parking space is located, is significantly different from the objects in the local market, e.g. the number of storeys, standard. Then the price of similar places, even in close proximity may differ significantly from the prices offered by the developer.

$\rightarrow$ pricing policy of the developer: on the primary housing market of the city of Cracow, there is a situation in which the unit prices of dwellings are dumped at the expense of high prices for parking spaces and belonging space. This policy is carried out particularly keen for developers who want to minimize the same housing unit prices, e.g. For limits on government programs, for example "Mieszkanie dla Młodych". The high price of parking space compensates for the financial losses resulting from the concessions in the price of housing (Jasińska 2015). As a result of such action, there are investments in which the prices of dwellings are among the lowest in the city, while the price of parking spaces reach a maximum ceiling.

$\rightarrow$ city local planning policy: the developer is obliged to provide the investment appropriate number of spaces. Their number determines the city council in the local spatial management plan, and when there is no plan, in decision on building and land development. Specified in planning documents factor of parking spaces directly affects the above-mentioned factor - pricing policy of the developer.

The above-mentioned factors as one of the many causes that in practice it is difficult to define the term of parking spaces market, and in particular to determine its spatial extent. Property appraiser must in any case make the analysis of individual factors that may affect the value of such objects.

\section{Local planning arrangements}

As mentioned before, the developer is obliged to provide the investment appropriate number of spaces. Their number determines the city council in the local spatial management plan, and when there is no plan, in decision on building and land development. In connection with the above, the analysis included determination of the applicable local spatial management plans from the city of Krakow in respect of the issue.

In accordance with the present situation in December 2016 in the city of Krakow, 145 plans were in force, of which 3 of them have been established as plans containing changes of the prior arrangements, so they were excluded from the analysis. Therefore, the analysis included 142 local spatial management plans, which cover the nearly $48 \%$ of the area of Krakow.

In the figure 4 areas of existing local spatial development plans are symbolized by a red color. As part of the study, the analysis included findings each of the local plans relating to the required number of parking spaces for new residential investments (multi-family housing). It should be noted that these findings apply generally to the total of all forms of parking spaces, including those aboveground.

Among the 142 analyzed local development plans, arrangements for parking spaces in the multi-family residential areas are included in 95 of them (nearly 67\%). In the vast majority, there is a record of them regulating the minimum required number of parking areas for new multi-family housing development. The most common one is given a specific numerical value - the ratio of the required number of parking spaces to the proposed residential units. In the case of the three plans is given compartment containing the minimum and maximum number of allowed parking spaces (also expressed as a ratio). Below (see Fig. 5) there is a chart showing the planning provisions relating to the issue discussed. 


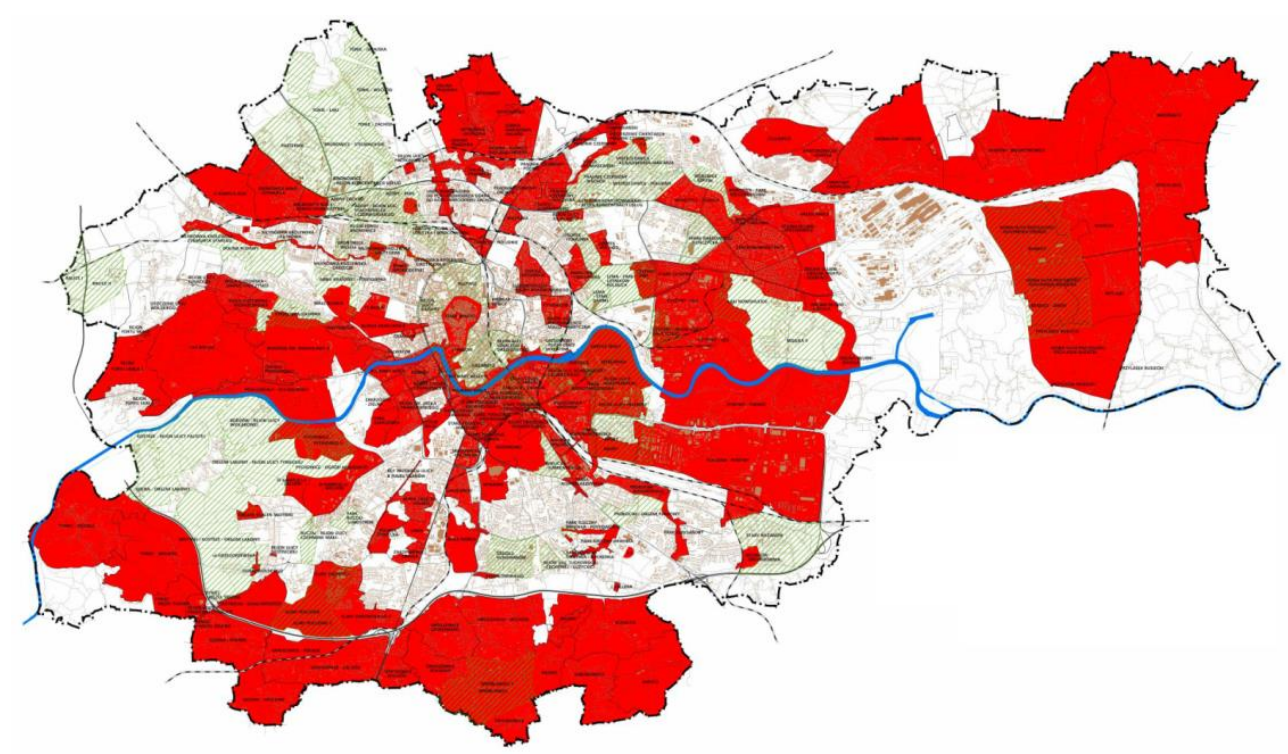

Fig. 4. Local spatial management planes in the city of Krakow - December 2016 (source: http://planowanie.um.krakow.pl/bppzoom/index.php)

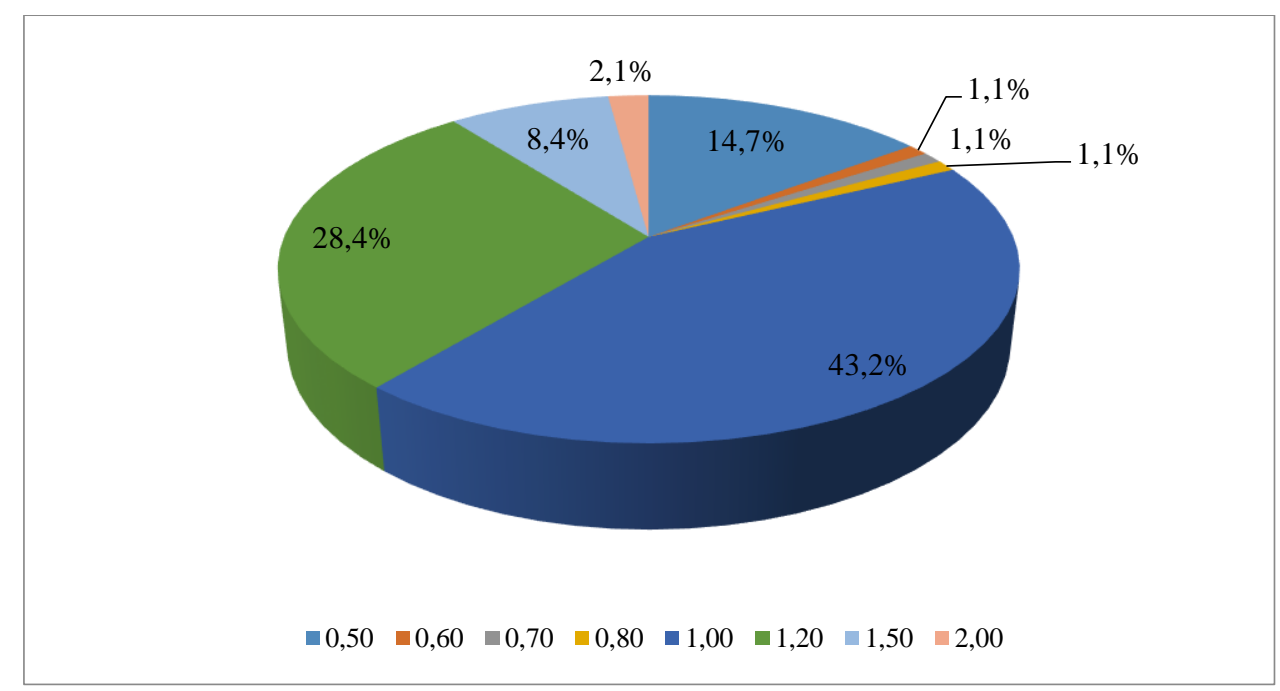

Fig. 5. The required number of parking places - arrangements of local spatial management plans (Source: own studies)

From the research carried out, it is clear that the vast majority of local plans involves the implementation of at least one parking space with respect to the number of completed dwellings (43.2\%). Slightly more than $28 \%$ of the plans used a greater factor of 1.2 . Nearly $15 \%$ are local plans, which require only 0.5 parking space per dwelling. About $10 \%$ of planning documents indicate the highest ratios - 1.5 space $(8.4 \%)$ and up 2 places (2.1\% of plans). The remaining $3.3 \%$ of plans are those that offer rates of between 0.6 to 0.9 parking space.

The above analysis shows that the vast majority of local zoning plans requires developers to the implementation of at least one parking space for one dwelling. A large part because 38.9\% of them also provides additional space, important, for example, in the perspective of guests of the building future residents. The study also noted that, in the context of changes to the local spatial development plans, for the two of them there were made the reduction of the parking spaces factor for the multi-family residence area.

It is worse in areas not covered by the local spatial management plans. For such areas are issued decisions on zoning and land use. Practice shows that the indicators used in these decisions differ significantly from the standards presented in the local spatial management plans and are at a much lower level (due to the lack of access to the content of these decisions in the context of this work was not carried out numerical analysis). 


\section{Conclusions}

As part of this study in the first place was made to systematize types of parking places, which can be found in trading on the Polish real estate market. In the next part there were made characteristics of primary market of parking spaces in selected areas of the city of Krakow. There were also outlined the characteristics of the market for the forming of its specificity. Next there was made an attempt to select for potential price-setting attributes of parking spaces. There were also pointed the practical difficulties faced by appraiser with a mandate to determine the market value of the parking space.

It was also carried out an analysis of the findings of local spatial management plans with respect to the required number of parking spaces for the planned investments in multi-family housing.

The overall conclusion is that the primary market of parking places is much less transparent than primary residential market. Price and value of such an object is determined by other factors than is the case with dwellings. The study indicated the potential attributes of price-setting, which may affect the estimated value of a parking space.

The proposed selection forms the basis for further research, in particular trying to determine the quantitative effect of each attribute.

Analysis of the findings of local zoning plans with respect to the required number of parking spaces, leads to the conclusion that the current plans for the most guarantee the realization of at least one per dwelling. Like other aspects of the real estate economy, the problem remains relatively small coverage area of the city by the findings of the most important planning document.

\section{Funding}

This work was carried out within the statutory studies of the AGH University of Science and Technology, Faculty of Mining Surveying and Environmental Engineering, Department of Geomatics No. 11.11.150.006.

\section{References}

Butryn K., Preweda E. 2016. Selected issues of establishing and functioning of the transmission easement, Geomatics and Environmental Engineering, vol. 10, no 1:33-44.

Jasińska, E. 2015. Legal and economic conditions for parking place management in the homeowners associations - Prawne i ekonomiczne warunki gospodarowania miejscem postojowym we wspólnotach mieszkaniowych, Świat Nieruchomości, Nr 94, Kraków.

Jasińska E. 2012. Wybrane metody statystyczne w analizie rynku nieruchomości (Chosen Statistical Method In Real Estate Market Analysis), AGH, Kraków, DOI: 10.13140/RG.2.1.2686.9204/1

Kucharska-Stasiak E. 2004. Nieruchomość w gospodarce rynkowej, Wydawnictwo Naukowe PWN, Warszawa.

Postanowienie. 2005. Postanowienie Trybunału Konstytucyjnego z dnia 14 grudnia 2005 roku, sygn. akt SK 24/05.

Puch P. 2010. Miejsce postojowe i miejsce parkingowe, Krakowski Rynek Nieruchomości, Nr 13, Kraków 2010.

Rozporządzenie. 2002. Rozporządzenie Ministra Infrastruktury z dnia 12 kwietnia 2002 r. w sprawie warunków technicznych, jakim powinny odpowiadać budynki i ich usytuowanie ( $\mathrm{Dz} . \mathrm{U}$. Nr 75, poz. 690 ze zm.).

Rozporządzenie. 2004. Rozporządzenie Rady Ministrów z dnia 21 września 2004 r. w sprawie wyceny nieruchomości i sporządzania operatu szacunkowego (Dz. U. 2004 nr 207 poz. 2109 ze zm.)

Raport. 2015. Urząd Miasta Krakowa - Wydział Rozwoju Miasta. 2016, Krakowski Rynek Nieruchomości 2015 - raport, Kraków.

Ustawa. 1994. Ustawa z dnia 24 czerwca 1994 r. o własności lokali. (Dz. U. 1994 nr 85 poz. 388 ze zm.)

Ustawa. 2003. Ustawa z dnia 27 marca 2003 r. o planowaniu i zagospodarowaniu przestrzennym (tekst jednolity na podstawie: $D z$. U. z 2015 r. poz. 199, 443, 774, 1265, 1434, 1713, 1777, 1830, 1890, wraz z późniejszymi zmianami)

Wyrok. 2012. Wyrok Naczelnego Sadu Administracyjnego z dnia 12 października 2012 r., sygn. akt II OSK 812/11. 